\title{
Greenhouse Monitoring and Controlling System, Study Case "Strawberry"
}

\author{
Istas Pratomo Manalu ${ }^{1}$, Sanita Simamora ${ }^{1}$, Ruben Mual Siregar ${ }^{1}$, \\ Alexius Humbang Manik ${ }^{1}$, Andriono Manalu ${ }^{2}$ \\ ${ }^{1}$ Computer Engineering, Faculty of Informatics and Electrical Engineering, Institut Teknologi Del, \\ Tobasamosir, North Sumatra 22381 \\ ${ }^{2}$ Department of Physics, Universitas HKBP Nomensen, Medan, Indonesia, 20155 \\ E-mail: istas.manalu@del.ac.id
}

\begin{abstract}
Abstrak: Penerapan teknologi di bidang pertanian telah mengalami kemajuan dan perkembangan terhadap ilmu teknologi. Teknologi yang lebih spesifik digunakan adalah IoT (Internet of Things), dimana pemanfaatan jaringan internet menjadi salah satu faktor utama dalam mengembangkan mesin-mesin teknologi yang bersifat otomatis guna meningkatkan sistem pertanian. Oleh karena itu penggunaan IoT adalah sangat bermanfaat dalam bidang pertanian khususnya dalam budidaya stroberi yang memerlukan pengendalian khusus dalam setiap proses pemeliharaannya yaitu untuk beberapa aktivitas utama seperti penyiraman, pemupukan, dan pemantauan suhu serta kondisi tanaman secara real-time. Melalui penelitian dan pengembangan ini diharapkan sistem IoT dapat membantu aktivitas budidaya stroberi yang dirancang menggunakan NodeRED sebagai visual programming dan terhubung dengan protokol MQTT sebagai protokol dalam transmisi data dan informasi. Node-RED sebagai teknologi terbaru dimanfaatkan untuk dapat memudahkan proses penerapan sistem IoT dan melakukan pengontrolan dan pemantauan terhadap setiap data dan perintah yang diterima dan dibuat. Metode penelitian dimulai dari pengumpulan data, mendesain model, mengumpulkan alat dan bahan, melakukan pengujian, implementasi alat kepada objek, dan evaluasi terhadap setiap proses implementasi yang telah berjalan. Target yang ingin dicapai dalam penelitian ini adalah mampu mengurangi tenaga petani, efisiensi waktu dengan adanya sistem automation, dan mampu menjaga proses pertumbuhan tanaman stroberi secara optimal.
\end{abstract}

Kata kunci: Internet of Things; Stroberi; MQTT; Node-RED; Monitoring; dan Controlling.

\begin{abstract}
The application of technology in agriculture has become several indicators of progress and developments in technological science. The more specific technology used in IoT (Internet of Things) that the use of the internet network is one of the main factors in developing automated technological machines to improve agricultural systems. Therefore, the use of IoT is very useful in agriculture, especially in strawberry cultivation, which requires s control in every maintenance process, namely for several main activities such as watering, fertilizing, and monitoring temperature and plant conditions in real-time. Through this research and development, it is hoped that the IoT system will be designed using Node-RED as visual programming and will connect to the MQTT protocol as a protocol in data and information transmission. Node-RED is the new technology that use to facilitate the process of implementing the IoT system and controlling and monitoring every data and order received and made. The research method starts from data collection, designing models, collecting tools and materials, conducting tests, implementing tools to objects, and evaluating each implementation process that has been running. The hopes and targets of the Greenhouse Monitoring and Controlling System, Study Case "Strawberry" can reduce farmer labor, time efficiency with a automation system, and be able to maintain the optimal growth process of strawberry plants.
\end{abstract}

Keywords: Internet of Things; Strawberry; MQTT; Node-RED; Monitoring; and Controlling. 


\section{PENDAHULUAN}

Potensi dari budidaya tanaman stroberi telah meningkat seiring dengan permintaan kebutuhan untuk jenis pangan ini. Hal ini dapat dilihat dari perkembangan komoditas dan produksi di berbagai daerah di Indonesia yang diikuti dengan banyaknya manfaat dari tanaman ini [1]. Namun pengolahan tanaman buah ini belum dilakukan secara optimal dilihat dari jumlah produktivitas yaitu sekitar 10 ton/ha tiap tahunnya. Salah satu provinsi di Indonesia yang perlu memperhatikan produksi stroberi yaitu Sumatera Utara dimana budidaya tanaman stroberi hanya popularitas di satu daerah yaitu di daerah Berastagi, sebab pada daerah tersebut banyak faktor yang sesuai untuk melakukan perawatan pada tanaman stroberi, yaitu udara yang sejuk (sekitar $16^{\circ} \mathrm{C}$ $25^{\circ} \mathrm{C}$ ), tanah yang subur, dan cuaca dataran tinggi yang mendukung [2].

Dibandingkan dengan daerah Toba, budidaya tanaman stroberi cukup sulit untuk dilakukan, karena memiliki suhu rata-rata yaitu $17^{\circ} \mathrm{C}-29^{\circ} \mathrm{C}$ dan tanah pada daerah Toba bercampur dengan tanah merah serta memiliki tingkat keasaman tanah yang tinggi sehingga kurang cocok untuk melakukan budidaya stroberi. Dalam usaha untuk membangun budidaya tanaman stroberi di daerah Toba, kami berupaya mengembangkan sistem IoT yang dapat menjadi solusi bagi masyarakat Toba untuk menjangkau batasan-batasan yang ada. Sistem IoT sudah sering digunakan dalam membantu bidang pertanian karena banyaknya teknologi terbaru dan alat-alat atau bahan yang dapat memudahkan aktivitas para petani [3].

Penggunaan sistem IoT ini dirancang untuk mengendalikan parameter-parameter yang mendukung proses perawatan untuk budidaya stroberi, yaitu suhu, kelembapan tanah, penyiraman air, dan pemupukan [4], [5]. Sensor-sensor yang biasa digunakan dalam teknologi IoT dapat membaca data suhu dan kelembapan tanah [4], [6]. Berbagai jenis aktuator menjalankan fungsi penyiraman, pemupukan, dan penurunan suhu udara. Serta teknologi wireless menghubungkan berbagai perangkat untuk dapat mengendalikan dan memantau budidaya stroberi dari jarak yang berjauhan.

Dalam menerapkan sistem IoT pada budidaya stroberi ini, digunakan Greenhouse [7],[8],[9] agar dapat memanfaatkan lahan kecil. Ruangannya yang tertutup dan memiliki pembatas dapat melindungi proses kerja untuk sistem rangkaian dari aktivitas alam seperti hujan atau hewan dan tumbuhan perusak. Penggunaan Greenhouse juga cukup efisien untuk penerapan sistem IoT, dimana ruangan yang terbatas mempermudah sistem mengendalikan suhu ruangan di dalam agar mencapai standar suhu yang baik bagi tumbuhan stroberi yang biasa berada di iklim dingin [10]. Oleh sebab itu peneliti sebagai tim pengembang berupaya membangun sistem IoT di dalam Greenhouse untuk dapat membudidayakan tanaman stroberi.

Dalam budidaya ini peneliti memanfaatkan teknologi IoT yaitu Node-RED untuk membangun sistem tersebut [11],[12]. Alasan untuk menggunakan Node-RED dalam proyek ini karena Node-RED sebagai teknologi visual programming dapat mengurangi pekerjaan pengembang dalam membangun code yang diaplikasikan ke setiap komponen [11]. Pada sistem ini memanfaatkan server dan browser dalam melakukan pemantauan dan pemeliharaan tanaman secara real-time. Pengguna yaitu pengolah lahan juga dapat melakukan pemantauan dari jarak jauh melalui monitor atau mobile mereka. Pemanfaatan teknologi Node-RED di dalam Greenhouse ini juga pernah dikembangkan oleh peneliti Universitas Islam Sultan Agung pada tahun 2018 dengan tujuan perbaikan kualitas Greenhouse bagi para petani.

Adanya sistem pemantauan dan pengontrolan menggunakan teknologi Node-RED ini diharapkan mampu membantu pekerjaan para petani dalam membudidayakan stroberi di dalam Greenhouse. Hasil dari penerapan dan perekaman data ini juga diharapkan dapat dimanfaatkan sebagai informasi acuan terhadap pengembangan teknologi dalam bidang pertanian di daerah Toba. 


\section{METODOLOGI}

\section{A. Desain Prototype Board}

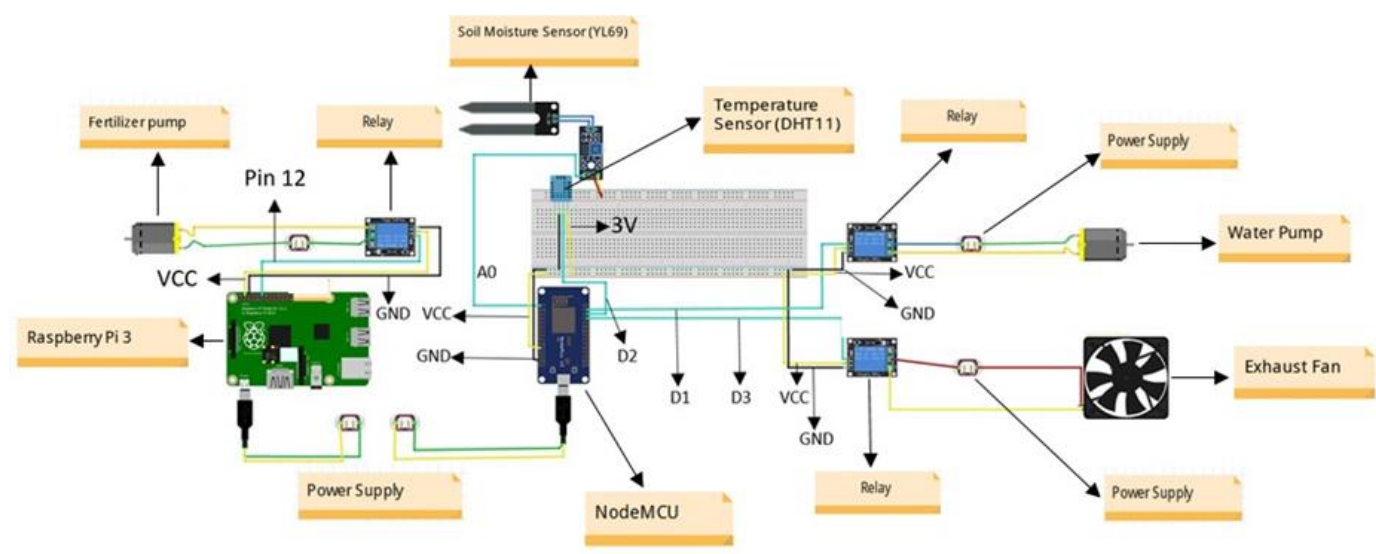

Gambar 1. Desain Prototype Board

Berdasarkan Gambar 1 di atas, dijelaskan desain rangkaian dari sistem yang dikembangkan. Pada mini-PC tersebut kemudian diinstal MQTT dan Node-RED. Semua perangkat yang membangun sistem ini terhubung ke satu jaringan $\mathrm{WiFi}$, dimana dengan penggunaan jaringan yang sama menjadi media pengiriman data dan informasi dari setiap perangkat.

\section{B. Transmisi Data Sistem}

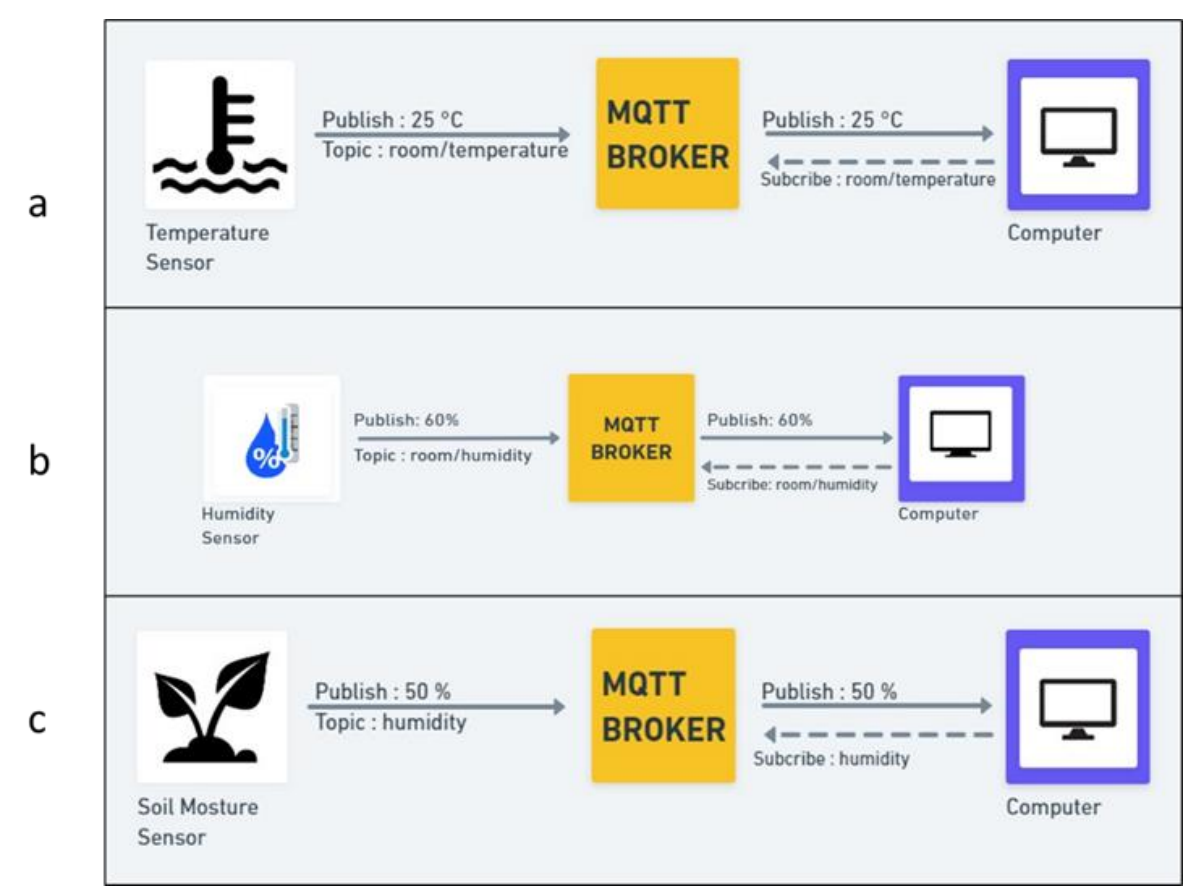

Gambar 2. Transmisi data sistem monitoring dan control greenhouse a) suhu udara,

b) kelembapan udara dan c) kelembapan tanah

Pada proses transmisi data suhu udara seperti pada Gambar 2a, sensor DHT 11 terhubung ke gateway yaitu NodeMCU, dimana terinstal library pubsubclient, library tersebut digunakan untuk menghubungkan node mcu ke MQTT dengan menggunakan topic yang sudah dibuat yaitu room/temperature untuk menginisialisasi data sensor sebagai publisher. Kemudian topic tersebut dikirim ke MQTT Broker yang terdapat di Raspberry sebagai penghubung antara publisher dengan topic room/temperature dengan subscriber room/temperature. Setelah itu, Node-RED yang telah terinstall di Raspberry menginisialisasi data yang diterima menggunakan node mqtt-in dan menampilkan data yang masuk ke dashboard untuk fungsi monitoring. 
38 | Istas Pratomo Manalu, et. al., Greenhouse Monitoring and Controlling System....,

Pada proses transmisi data kelembapan udara seperti pada Gambar 2b, sensor DHT 11 telah terhubung ke NodeMCU sebagai mikrokontroler tambahan dan telah dilakukan penginstalan library pubsubclient. Library ini menguhubungkan data yang diterima oleh NodeMCU ke Raspberry yang telah terinstal MQTT Broker sehingga data diinisialisasi sebagai publisher yang memiliki topik room/humidity dan dihubungkan dengan subscriber yang sama yaitu room/humidity. Selanjutnya, data kelembapan udara yang telah dibawa oleh topik tersebut diterima oleh Node-RED dalam node mqtt-in untuk ditampilkan di dashboard dan dikirim ke penyimpanan basis data InluxDB melalui node influxdb.

Sedangkan untuk transmisi data kelembapan tanah seperti pada Gambar 2c, sensor kelembapan tanah telah terhubung ke NodeMCU, dimana pada NodeMCU telah terinstal library pubsubclient. Library tersebut berfungsi menghubungkan data yang dikirim oleh NodeMCU ke MQTT menggunakan topik humidity. Topik humidity menginisialisasi data sensor kelembapan tanah dan dikirim ke MQTT Broker di Raspberry, sehingga data dengan topik humidity sebagai publisher dihubungkan dengan subscriber humidity. Kemudian topic humidity dengan pesan adalah nilai dari sensor kelembapan tanah, ditampilkan ke dashboard Node-RED dengan penggunaan node mqtt-in untuk input data kelembapan tanah yang dapat diakses pengguna.

\section{Flowchart Sistem}

\section{Monitoring dan Controlling berdasarkan Sensor Suhu dan Kelembapan Udara}

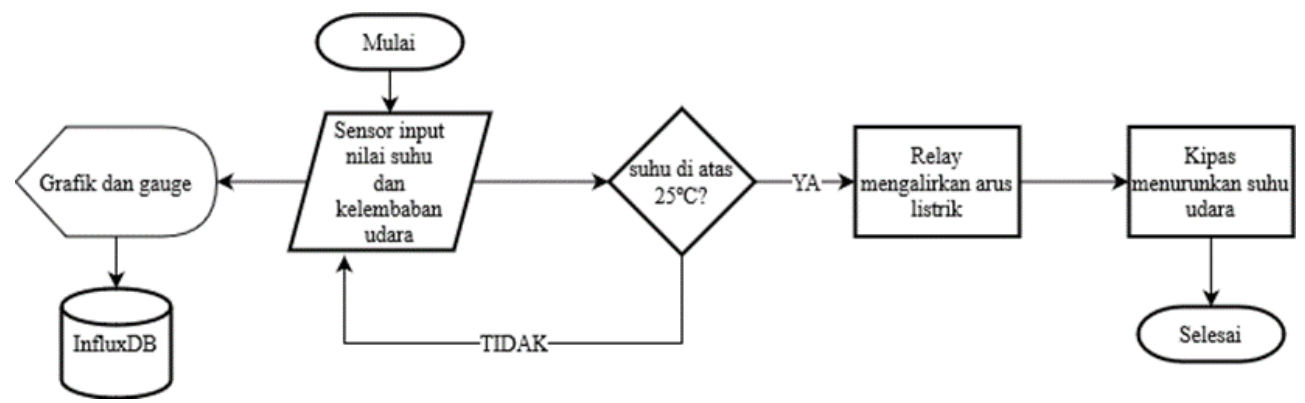

Gambar 3. Flowchart monitoring dan controlling berdasarkan sensor suhu dan kelembapan udara

Sistem yang dikembangkan bekerja untuk melakukan monitoring data suhu dan kelembapan udara serta melalukan pengendalian suhu di dalam Greenhouse secara otomatis seperti yang ditunjukkan oleh Gambar 3. Pada mulanya, sistem merekam data suhu dan kelembapan udara melalui sensor DHT 11. Kemudian data dikirim ke Raspberry dan diolah oleh aplikasi Node_RED dengan menampilkan data ke dashboard dalam bentuk grafik garis dan gauge serta disimpan ke dalam basis data jenis InfluxDB. Selanjutnya dalam melakukan pengendalian suhu udara di dalam ruangan, data yang diinput diolah oleh NodeMCU untuk memeriksa kondisi yang terjadi berdasarkan data suhu udara. Jika data tidak mengalami kenaikan di atas $25^{\circ} \mathrm{C}$ maka data hanya terus berjalan, tetapi jika data mengalami kenaikan di atas standar maka data tetap diinput dan Relay 1 diaktifkan untuk menghidupkan Kipas

\section{Monitoring dan Controlling berdasarkan Sensor Kelembapan Tanah}

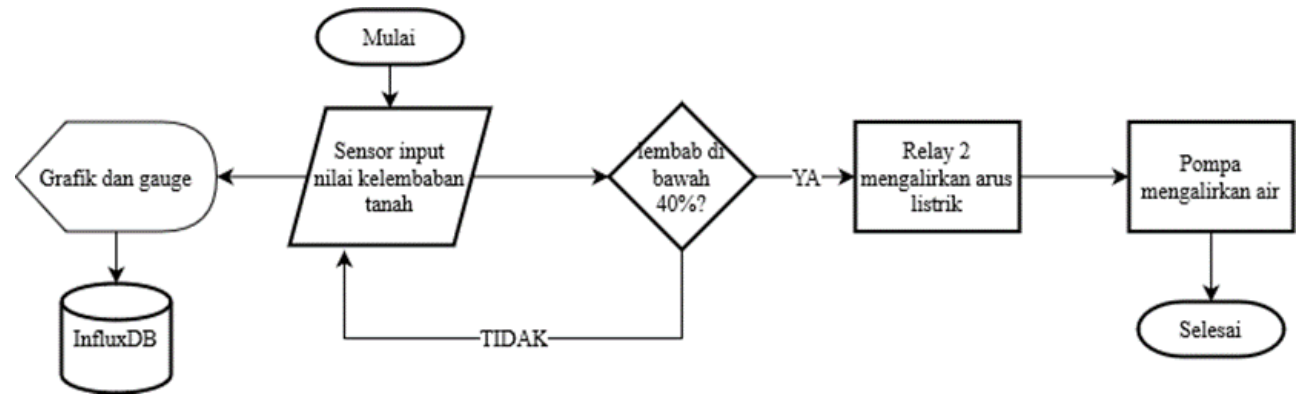

Gambar 4. Flowchart monitoring dan controlling berdasarkan sensor kelembapan tanah 
Untuk kasus kelembapan tanah seperti Gambar 4, sistem yang dikembangkan bekerja untuk melakukan monitoring data kelembapan tanah serta melalukan pengendalian kelembapan tanah dengan penyiraman air secara otomatis pada tanaman stroberi. Alur kerja diawali dari sensor YL 26 yang merekam kelembapan tanah. Kemudian untuk melakukan pemantauan data dikirim ke Raspberry dan diolah oleh aplikasi Node_RED dengan menampilkan data ke dashboard dalam bentuk grafik garis dan gauge serta disimpan ke dalam basis data jenis InfluxDB. Setelah itu, untuk mengendalikan kelembapan tanah, data yang diinput diolah oleh NodeMCU untuk memeriksa kondisi yang terjadi berdasarkan data kelembapan tanah. Jika tanah termasuk dalam jenis tanah kering yaitu berada pada kelembapan di bawah 40\%, maka data tetap direkam dan Relay 2 diaktifkan untuk pompa penyiraman air. Tetapi ketika jenis tanah berada pada angka di atas $40 \%$, maka sistem hanya input data dari sensor.

\section{Controlling untuk Pemupukan}

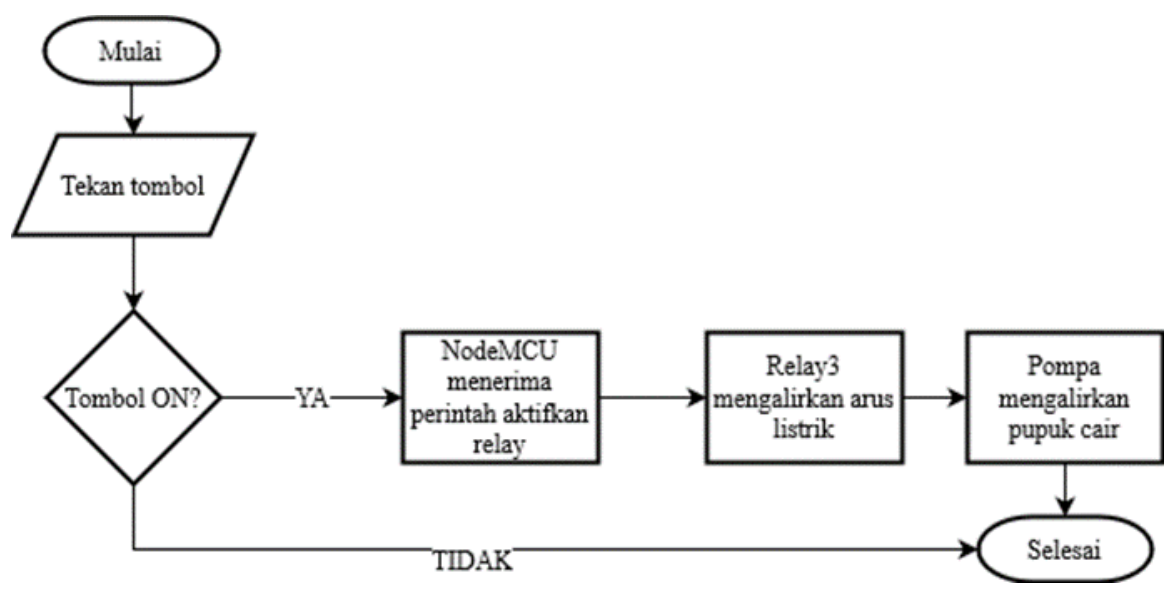

Gambar 5. Flowchart controlling pemupukan

Pada Gambar 5 di atas, terdapat alur untuk controlling terhadap pompa pemupukan yang dilakukan secara semi-otomatis. Sistem memiliki tombol pada bagian pemupukan di dashboard Node-RED. Ketika user menekan tombol ON, maka Raspberry mengirim perintah kepada NodeMCU untuk mengaktifkan aktuatornya. NodeMCU kemudian mengaktifkan Relay ketiga untuk mengalirkan arus listrik ke perangkat pompa untuk mengalirkan pupuk cair. Jika user tidak menekan tombol, maka tidak ada yang terjadi.

\section{Monitoring dari Kamera}

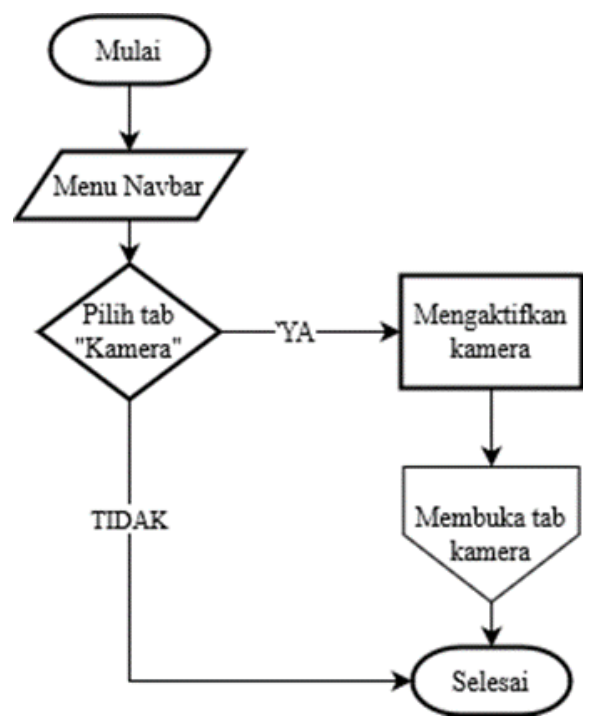

Gambar 6. Flowchart monitoring dari kamera 
40 | Istas Pratomo Manalu, et. al., Greenhouse Monitoring and Controlling System....,

Monitoring keadaan stroberi dan bagian dalam Greenhouse melalui kamera yang langsung tersambung ke Raspberry sebagai mikrokontroler, yaitu: Terdapat menu navbar yang menyediakan 2-tab yaitu tab room sebagai homepage dan $t a b$ kamera sebagai penampil hasil tangkapan kamera di dashboard Node-RED. Jika user menekan tab kamera, maka secara otomatis mengaktifkan kamera dan membuka tab atau halaman untuk menampilkan hasil dari kamera. Jika tidak, maka kamera tidak aktif.

\section{Desain Greenhouse}

Berikut ini adalah bentuk Greenhouse berdasarkan sisi luar yang telah dirancang untuk dapat mengalirkan udara yang dikeluarkan oleh perangkat Exhaust Fan dan dapat menarik udara dari luar melalui celah-celah ventilasi.

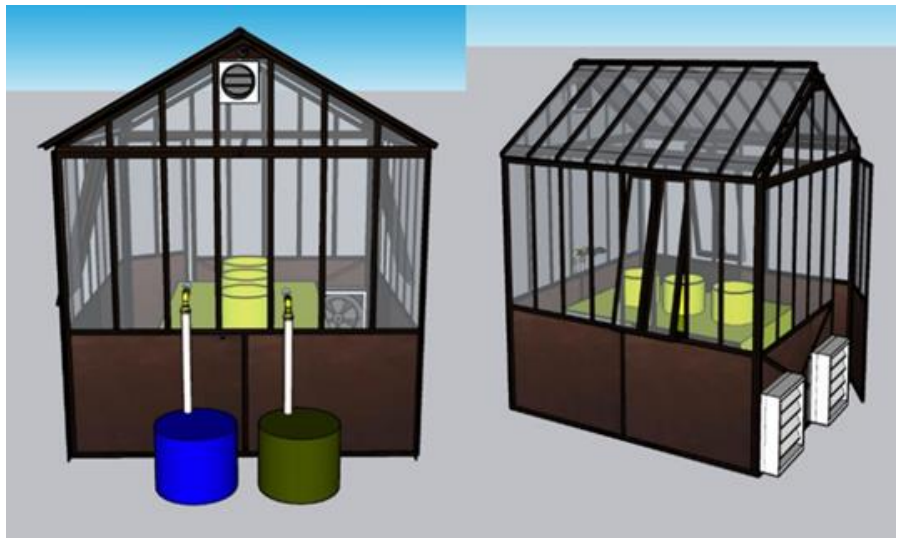

Gambar 7. Bentuk Luar Greenhouse

Berdasarkan Gambar 7 di atas adalah target rancangan Greenhouse yang diwakili oleh setiap komponen penting dari sistem ini. Greenhouse dibangun menggunakan kerangka baja yang tahan terhadap karat dan pelindung dilapisi oleh Plastik UV yang dapat mengurangi efek sinar UV dari matahari. Komponen-komponen untuk rangkaian sistem di dalam Greenhouse ini dihubungkan melalui jaringan internet, dimana sensor dan aktuator menggunakan NodeMCU untuk dapat melakukan transmisi data.

\section{E. Implementasi Prototype}

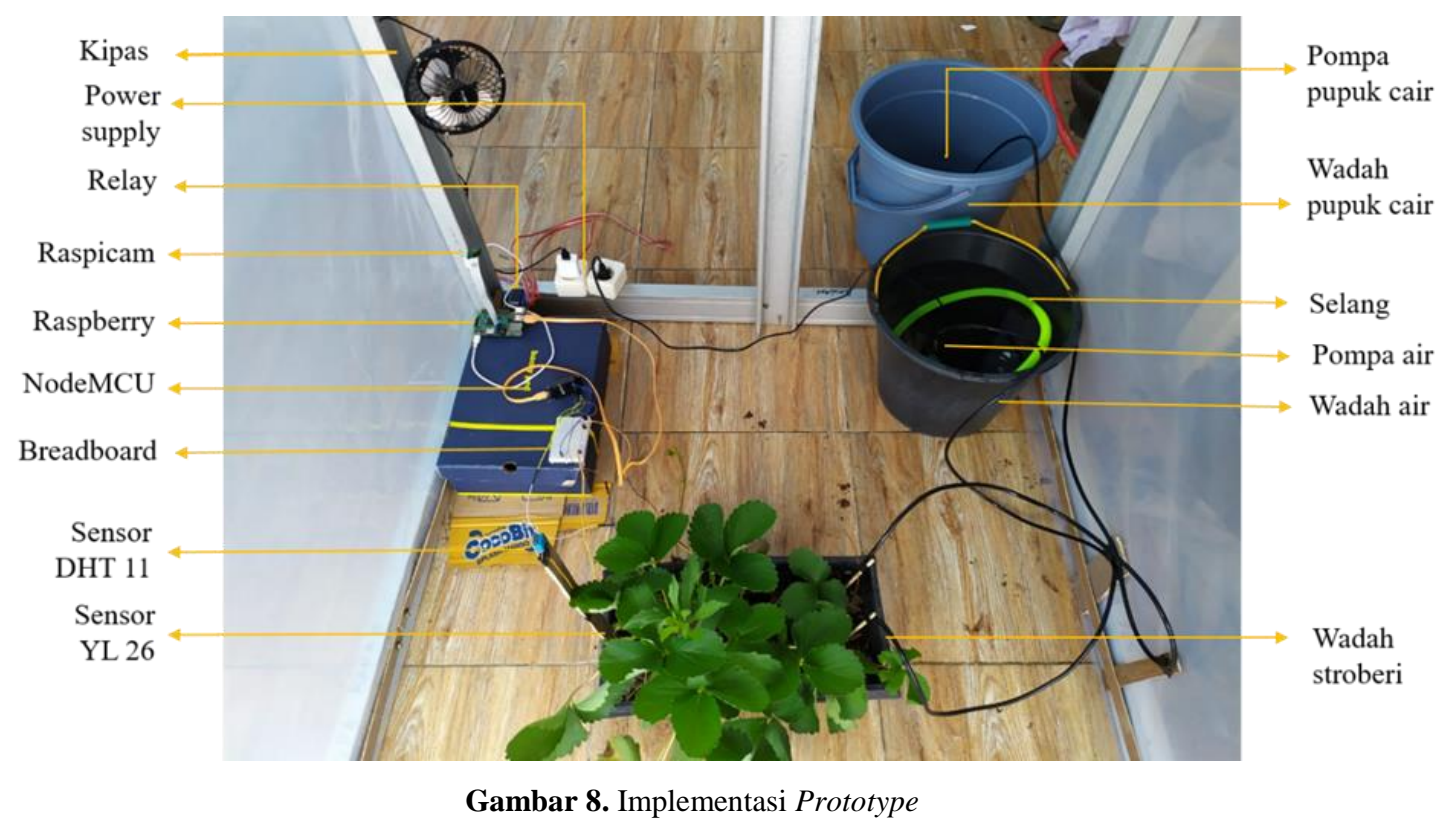

Implementasi prototype pada penelitian ini terdiri dari beberapa komponen utama dan komponen pendukung seperti pada Gambar 8. Komponen utama yaitu Raspberry, Node MCU, Sensor DHT 11, Sensor Kelembapan Tanah, Relay, Kipas, Power Supply, dan Pompa. 
Pengendalian suhu dilakukan melalui sensor DHT 11 yang diletakkan di dalam Greenhouse dan dekat dengan tanaman untuk dapat mendeteksi suhu udara di ruangan tersebut. Pada implementasi pengukuran suhu dan kelembapan udara, selain sensor peralatan yang digunakan adalah kabel jumper sebagai media transmisi data, NodeMCU sebagai perangkat penerima data dan Raspberry sebagai mikokontroler yang mengolah dan menyimpan data.

Kemudian untuk implementasi perangkat yang menurunkan suhu di dalam ruangan digunakan relay sebagai aktuator yang berfungsi mengalirkan arus listrik ke kipas. Sensor kelembapan tanah yang dipasang ke tanah secara langsung dimana sensor tidak sepenuhnya menancap ke tanah dan hanya lempengan konduktor yang berada di dalam tanah. Hal ini disebabkan oleh lempengan tersebut mengandung bahan logam yang menjadikannya sebagai media untuk mengukur tingkat kelembapan tanah, dimana air yang mengenai lempengan ini mengalirkan tegangan analog ke NodeMCU. Oleh karena itu, sensor ini terhubung ke pin analog pada NodeMCU untuk dibubah menjadi tegangan digital.

Kemudian untuk melakukan aktivitas penyiraman otomatis diperlukan beberapa perangkat yaitu NodeMCU terhubung ke relay kedua untuk menghidupkan pompa air yang mengalirkan air ke tanah. Pada implementasinya, pompa air ini menggunakan selang yang terbuat dari plastik untuk memindahkan air dari ember sebagai wadah ke pot tanaman stroberi. Untuk fungsi pemupukan, di desain hanya bekerja ketika user memberikan perintah melalui dashboard dengan input tombol ON. Kemudian melalui NodeMCU yang menerima perintah menghubungkan perintah tersebut ke relay ketiga. Relay ketiga aktif untuk menghidupkan pompa kedua yang mengalirkan pupuk cair ke atas tanah.

Untuk melengkapi sistem ini, peneliti membuat pemantauan kondisi tanaman di dalam greenhouse dengan memanfaatkan modul kamera. Modul ini hanya terhubung ke Raspberry sebagai mikrokontroller yang menampilkan hasil kondisi tanaman tanaman stroberi dalam bentuk video streaming di dashboard yang tersedia.

\section{HASIL DAN PEMBAHASAN}

Peneliti telah berhasil melakukan beberapa tahapan pengujian untuk memastikan system yang dibangun dapat bekerja sesuai dengan tujuan yang ingin dicapai. Dimulai dari pengujian fungsi setiap microcontroller sensor, aktuator, aplikasi Node-RED yang terhubung ke beberapa perangkat pendukung yaitu InfluxDB, Grafana, dan beberapa perangkat lainnya yang disusun dalam satu tempat yaitu Greenhouse. Pengujian ini dilakukan selama 10 hari untuk menguji apakah sistem ini dapat diimplementasikan secara real-time ke tanaman stroberi. Waktu pengujian juga dilakukan selama 6 jam dengan start waktu yang dimulai dari jam 8 atau 9 pagi sampai selesai jam 3 sore karena pada rentang waktu tersebut terdapat perubahan data (baik peningkatan atau penurunan) untuk suhu udara, kelembapan udara, dan kelembapan tanah. Kedua jenis data ini direkam sebanyak 1 kali dalam 30 detik untuk merekam data lebih cepat dan berdasarkan pengujian yang telah dilakukan, data dapat berubah 1 atau 2 kali dalam 1 menit.

\section{A. Pengujian Pemantauan dan Pengendalian Berdasarkan Sensor Suhu dan Kelembapan Udara}

Pada proses ini sensor DHT 11 dapat mendeteksi suhu dan kelembapan udara dari ruangan Greenhouse dan ditampilkan ke dashboard di Node-RED. Pada pengujian ini dilakukan monitoring untuk data suhu dan kelembapan udara untuk dilakukan analisa. Kemudian sistem pada NodeMCU mengolah data tersebut sesuai dengan program yang telah dibuat. Ketika suhu di dalam Greenhouse berada di atas $25^{\circ} \mathrm{C}$, maka sistem secara otomatis mengaktifkan relay untuk menggerakkan kipas. Berdasarkan pengujian yang telah dilakukan sebelumnya oleh tim pengembang, suhu udara di dalam Greenhouse masih cukup panas dan hanya turun 1 sampai $2^{\circ} \mathrm{C}$ sejak kipas dihidupkan. Oleh sebab itu, tim pengembang melakukan penambahan kipas menjadi dua buah dan lubang untuk sirkulasi udara pada dinding plastik UV pelindung Greenhouse diperbanyak.

Pada fungsi pemantauan, user dapat memantau data kondisi tanaman di Greenhouse dengan mengakses IP address Node-RED tersebut. Data yang dibaca oleh sensor itu juga dikirimkan ke server yaitu Raspberry Pi, kemudian data disimpan ke database InfluxDB. Database tersebut dapat diakses melalui grafana dalam bentuk grafik. Berdasarkan pengujian yang telah dilakukan, sensor DHT 11 merekam data suhu dan kelembapan udara dengan berbagai karakteristik dan peristiwa yang terjadi. Rangkuman informasi yang terjadi pada saat pengujian sistem selama 10 hari untuk data suhu udara pada Tabel 1. Suhu udara dan kelembapan udara pada Tabel 2. Kelembapan udara berikut ini. 
42 | Istas Pratomo Manalu, et. al., Greenhouse Monitoring and Controlling System....,

Tabel 1. Suhu udara

\begin{tabular}{cccccc}
\hline Hari ke- & $\begin{array}{c}\text { Nilai } \\
\text { minimun }\end{array}$ & $\begin{array}{c}\text { Nilai } \\
\text { maksimum }\end{array}$ & $\begin{array}{c}\text { Nilai paling } \\
\text { banyak muncul }\end{array}$ & $\begin{array}{c}\text { Nilai } \\
\text { rata-rata }\end{array}$ & Cuaca \\
\hline 1 & 21 & 27 & 22 & 23.18235 & Hujan badai \\
2 & 23.7 & 28 & 27 & 25.99507 & Hujan \\
3 & 23 & 26 & 25 & 24.33688 & Berawan \\
4 & 24 & 28 & 25 & 25.6242 & Normal \\
5 & 22.7 & 30.2 & 29 & 26.85422 & Normal \\
6 & 24 & 28 & 26 & 25.92792 & Normal \\
7 & 26 & 29 & 28 & 27.62881 & Normal \\
8 & 24.5 & 32 & 30 & 27.91344 & Normal \\
9 & 24.7 & 31.3 & 29 & 28.26631 & Normal \\
10 & 23 & 30 & 29 & 26.9788 & Berawan \\
\hline
\end{tabular}

Tabel 2. Kelembapan udara

\begin{tabular}{cccccc}
\hline Hari ke- & $\begin{array}{c}\text { Nilai } \\
\text { minimun }\end{array}$ & $\begin{array}{c}\text { Nilai } \\
\text { maksimum }\end{array}$ & $\begin{array}{c}\text { Nilai paling } \\
\text { banyak muncul }\end{array}$ & $\begin{array}{c}\text { Nilai } \\
\text { rata-rata }\end{array}$ & Cuaca \\
\hline 1 & 75 & 95 & 95 & 92.07324 & Hujan badai \\
2 & 73.5 & 95 & 95 & 88.19332 & Hujan \\
3 & 88 & 95 & 95 & 94.86649 & Berawan \\
4 & 44.7 & 95 & 95 & 67.74427 & Normal \\
5 & 44 & 57.5 & 47 & 48.62667 & Normal \\
6 & 44.7 & 84.7 & 50 & 55.43657 & Normal \\
7 & 47 & 65 & 51 & 55.21159 & Normal \\
8 & 50.3 & 70 & 54.8 & 59.14249 & Normal \\
9 & 51 & 74.7 & 64 & 61.75637 & Normal \\
10 & 57 & 79 & 61 & 65.78082 & Berawan \\
\hline
\end{tabular}

Dalam proses menganalisa keseluruhan hasil data dari fungsi pemantauan dan pengendalian berdasarkan sensor suhu dan kelembapan udara di dalam Greenhouse berikut ini disajikan grafik dari nilai rata-rata suhu dan kelembapan udara dalam 10 hari pengujian pada Gambar 9.
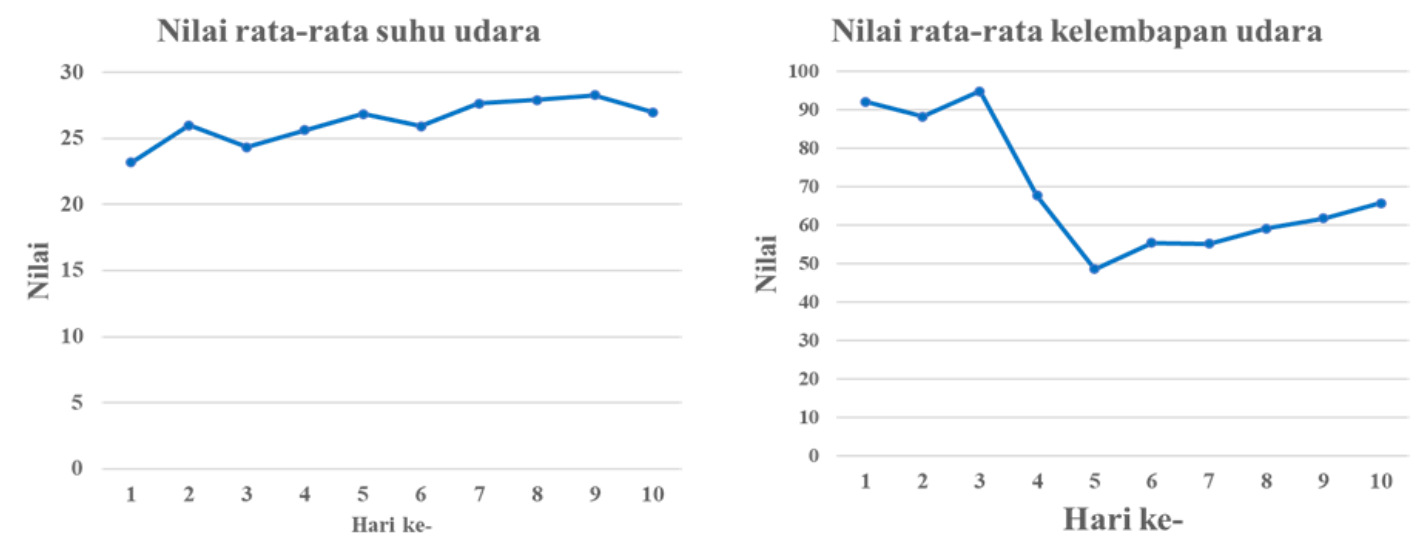

Gambar 9. Grafik suhu dan kelembapan udara untuk 10 hari 
Dari data yang diperoleh, nilai suhu (Gambar 9a) pada hari pertama adalah nilai yang paling kecil sedangkan nilai kelembapan udara cukup tinggi hal ini dikarenakan cuaca pada saat itu sedang mengalami hujan. Kemudian di hari kedua nilai suhu naik sebanyak $2.8^{\circ} \mathrm{C}$ dan kelembapan udara (Gambar 9b) masih tergolong tinggi yaitu $88 \%$ karena cuaca pada saat itu masih hujan tetapi tidak selama pada hari pertama. Pada hari ketiga, nilai rata-rata suhu turun kembali ke angka 24 dan memiliki nilai kelembapan udara paling tinggi karena data yang terekam hanya 3 jam sejak sistem dihidupkan dan dipengaruhi juga oleh cuaca yang tidak cukup panas atau berawan. Selanjutnya di hari keempat hingga hari kesembilan, nilai rata-rata suhu udara terus naik hingga ke angka $28.2^{\circ} \mathrm{C}$ dan kelembapan udara berada pada angka $48 \%-61.7 \%$ dikarenakan cuaca selama 5 hari tersebut berada pada status normal atau tidak mengalami hujan. Pada hari terakhir, suhu udara turun kembali menjadi $26.9^{\circ} \mathrm{C}$ dan tingkat kelembapan naik menjadi $65.7 \%$ dikarenakan cuaca saat itu berawan dan tidak lebih panas dari hari sebelumnya.

Berdasarkan analisa tersebut, cuaca sangat mempengaruhi kondisi suhu dan kelembapan udara di dalam Greenhouse. Semakin cerah atau panas cuaca maka semakin tinggi dan cepat pula peningkatan data suhu yang terekam oleh sistem. Begitu juga sebaliknya untuk cuaca hujan yang terjadi selama masa pengujian turut mempengaruhi pergerakan perubahan suhu yang menjadi lambat dan tidak pada angka yang tinggi. Namun sistem belum mampu menurunkan atau mempertahankan suhu pada standar yang dirancang yaitu suhu udara di bawah $25^{\circ} \mathrm{C}$. Kemudian, berdasarkan pengujian yang dilakukan selama 10 hari, nilai rata-rata suhu dan kelembapan udara memiliki pengaruh satu sama lain dimana nilai suhu yang tinggi cenderung memiliki nilai kelembapan udara yang rendah, hal ini disebabkan peningkatan suhu menghasilkan proses pengembunan (prespitasi) terhadap molekul air yang ada di udara sehingga muatan air yang terkandung di udara (kelembapan udara) menurun [6]. Dari analisa tersebut dapat diketahui bahwasanya sensor suhu dan kelembapan udara bekerja dengan baik dan kelembapan udara yang dipantau belum dapat memenuhi standar kelembapan udara yang baik (80-90\%) bagi stroberi dimana kelembapan udara yang baik hanya ditemukan ketika suhu udara rendah dan cuaca sedang hujan.

Berdasarkan pengujian yang telah dilakukan untuk parameter kelembapan tanah menggunakan sensor kelembapan tanah memiliki berbagai karakter yang ada sehingga menghasilkan nilai-nilai yang berbeda juga. Berikut ini rangkuman informasi kelembapan tanah pada Tabel 3 untuk data kesepuluh hari.

Tabel 3. Kelembapan tanah

\begin{tabular}{ccccccc}
\hline Hari ke- & $\begin{array}{c}\text { Nilai } \\
\text { minimun }\end{array}$ & $\begin{array}{c}\text { Nilai } \\
\text { maksimum }\end{array}$ & $\begin{array}{c}\text { Nilai paling } \\
\text { banyak muncul }\end{array}$ & $\begin{array}{c}\text { Nilai } \\
\text { rata-rata }\end{array}$ & Status pompa air & Cuaca \\
\hline 1 & 31.93 & 70.12 & 66.02 & 56.75 & Aktif & Hujan badai \\
2 & 38.38 & 70.31 & 48.54 & 58.38 & Aktif & Hujan \\
3 & 46.09 & 51.17 & 47.46 & 48.55 & Tidak diketahui & Berawan \\
4 & 43.07 & 51.66 & 50.68 & 48.79 & Tidak aktif & Normal \\
5 & 34.57 & 70.31 & 63.09 & 60.25 & Aktif & Normal \\
6 & 36.62 & 70.31 & 66.02 & 63.14 & Aktif & Normal \\
7 & 45.02 & 53.91 & 48.54 & 48.48 & Tidak Aktif & Normal \\
8 & 31.93 & 70.31 & 60.45 & 53.11 & Aktif & Normal \\
9 & 44.53 & 49.61 & 45.61 & 46.22 & Tidak Aktif & Normal \\
10 & 17.09 & 49.12 & 46.88 & 45.37 & Aktif & Berawan \\
\hline
\end{tabular}

Dalam proses menganalisa data pengujian fungsi pemantauan dan pengendalian berdasarkan sensor kelembapan tanah untuk kesepuluh hari, disajikan data dalam bentuk grafik pada Gambar 10 berikut ini menggunakan nilai rata-rata dari setiap hari pengujian. 


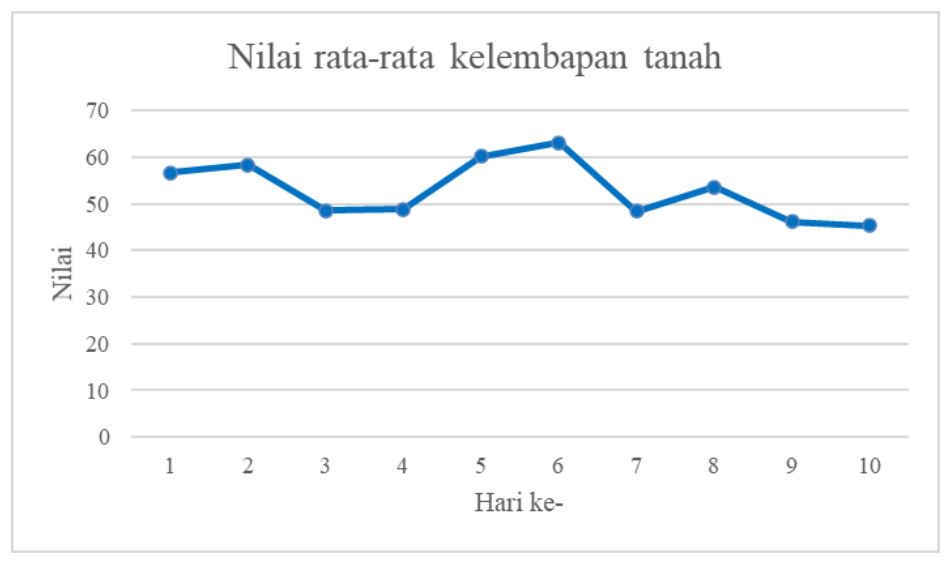

Gambar 10. Grafik nilai rata-rata kelembapan tanah

Berdasarkan Gambar 10, dapat dilihat grafik kelembapan tanah yang bergerak tidak stabil dimana pada hari pertama nilai rata-rata kelembapan tanah berada pada nilai kelembapan tanah $56 \%$ karena pada hari tersebut tidak panas dan pergerakan angka kelembapan tanah cukup lama untuk menjadi naik yang memicu terjadinya penyiraman. Selanjutnya di hari kedua nilai rata-rata kelembapan tanah masih berada pada angka dibawah $60 \%$ tepatnya pada angka $58.37 \%$ karena pada hari tersebut cuaca masih hujan dan setelah terjadi penyiraman tanah tidak menjadi cepat kering yang membuat nilai resistensi tidak cepat naik. Pada hari ketiga nilai rata-rata kelembapan tanah turun ke angka 48.5\% karena pada hari tersebut data yang direkam hanya sampai jam 1 siang dan nilai kelembapan dominan pada angka sekitar $47.4 \%$. Kemudian pada hari keempat, nilai kelembapan tanah naik hanya $0.2 \%$ dimana pada saat pengujian tersebut nilai berada ada angka $50 \%$ dan $40 \%$.

Selanjutnya di hari kelima, nilai kelembapan naik kembali ke angka $60 \%$ dimana pada hari tersebut data tidak dapat diakses seluruhnya dan menghasilkan angka rata-rata yang cukup tinggi. Pada hari keenam data naik ke angka $63.1 \%$ akibat dari proses pengaktifan pompa yang cepat sehingga menghasilkan nilai pada angka $63 \%$ dan tetap berada diatas $50 \%$. Lalu pada hari ketujuh data turun hingga ke angka $48 \%$ diakibatkan oleh tidak adanya proses penyiraman yang terjadi pada hari pengujian tersebut. Pada hari kedelapan nilai menjadi naik ke angka 53\% karena pada hari tersebut terjadi penyiraman air dan nilai yang dirata-ratakan telah naik ke angka di atas 50\%. Pada hari kesembilan nilai turun kembali ke angka 46\% karena pada hari tersebut tidak terjadi penyiraman air dan pada hari terakhir nilai tetap turun walaupun telah terjadi penyiraman karena pada data tersebut nilai dominan di angka $46 \%$.

Sehingga berdasarkan hasil analisis tersebut, suhu udara yang ada di dalam Greenhouse mempengaruhi tingkat kelembapan tanah, semakin tinggi suhu udara maka semakin besar radiasi atau panas yang diserap oleh tanah sehingga mengurangi kadar air di dalam tanah. Kemudian didapatkan hasil bahwasannya penyiraman otomatis terjadi pada waktu sebelum jam 12 siang ketika terjadi peningkatan suhu yang sejalan dengan penurunan tingkat kelembapan tanah. Kemudian tingkat kelembapan tanah tersebut terbukti meningkat ketika penyiraman telah dilakukan.

\section{B. Hasil Pengujian Pemantauan Menggunakan Kamera}

Pada proses pemantauan, kamera diaktifkan dalam keadaan semi-otomatis dimana user dapat kapan saja mengaktifkan kamera selama sistem masih aktif dan tersambung ke sumber daya listrik. User dapat menekan navbar pada pojok kiri atas yang ada pada dashboard menuju ke tab Camera dan kamera secara otomatis menyala. Hasil dari kamera ada pada Gambar 11 dengan spesifikasi kualitas gambar 5 megapixel adalah cukup untuk memantau keadaan sekitar Greenhouse dan dapat melihat buah stroberi pada jarak paling jauh yaitu 2 meter dari objek [13]. 


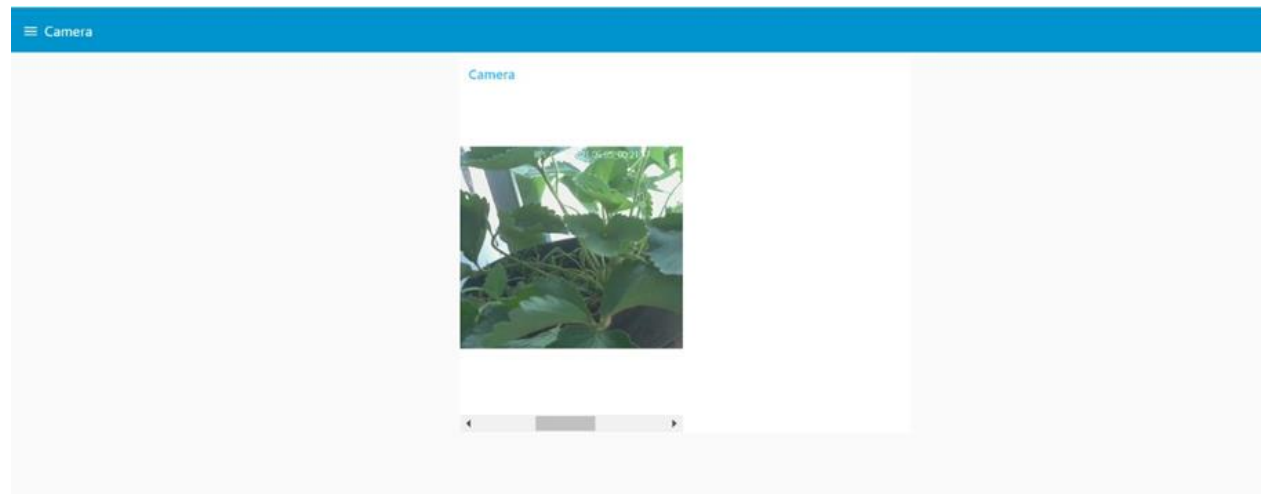

Gambar 11. Tampilan dari kamera raspi pada Greenhouse

\section{Pengujian Pompa Pupuk Cair}

Pada tahap ini, user sebelumnya telah mendapat email yang berisi pemberitahuan untuk melakukan pemupukan, dimana email ini muncul setiap hari Minggu pukul 9 pagi. Notifikasi ini dijadwalkan 1 kali dalam seminggu mengikuti dengan standar pemupukan yang baik bagi tanaman stroberi. Berikut ini adalah Gambar 12 sebagai contoh email yang masuk ke akun Gmail pengguna.

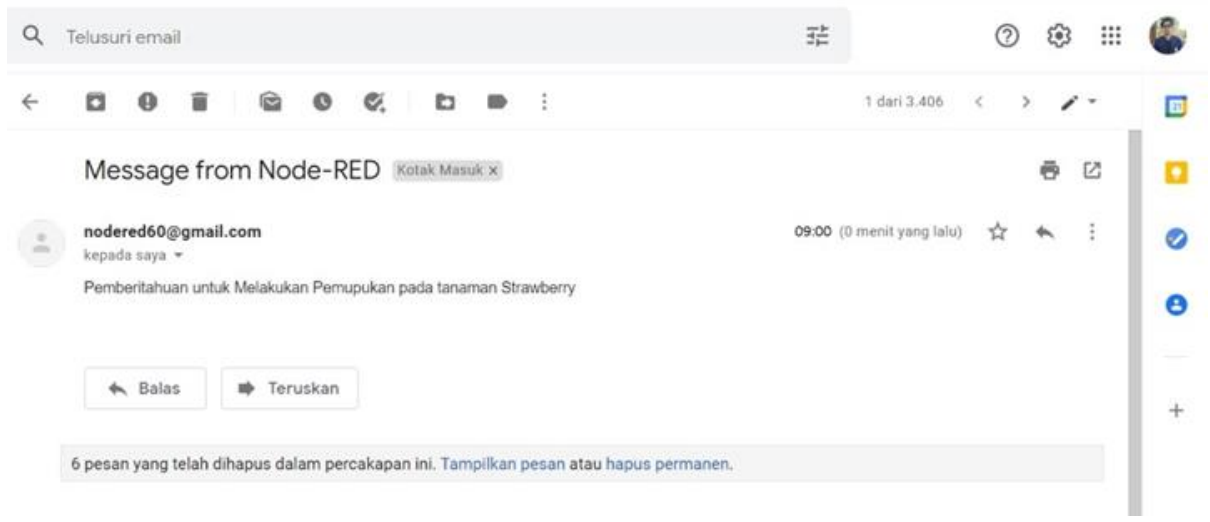

Gambar 12. Email pemberitahuan untuk melakukan pemupukan

Pemupukan ini dilakukan oleh user secara semi otomatis, dimana user bisa menekan tombol ON pada bagian pupuk yang terdapat di dashboard Node-RED seperti pada Gambar 13 berikut ini.

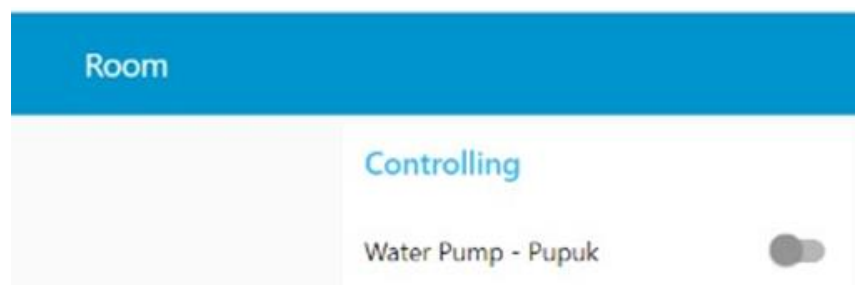

Gambar 13. Pengendalian pupuk cair di dashboard

Setelah klik tombol ON, maka langsung mengaktifkan relay untuk menghidupkan water pump yang menyalurkan pupuk cair ke tanaman stroberi. Aktivitas ini dilakukan pada awal pengujian dengan mengikuti standar banyaknya pupuk yaitu 1:50 antara pupuk asli dan air serta dilakukan satu kali untuk setiap minggu.

Pada pengecekan proses penyiraman air, dapat dilakukan dengan mengecek email yang masuk berdasarkan kondisi relay. Jika relay aktif maka email berisi pesan "Penyiraman dilakukan" dikirim ke akun email pengguna sejak user menekan tombol ON. Sedangkan ketika status pupuk berhenti atau relay non aktif kembali, maka email berisi "Penyiraman telah dilakukan" seperti pada Gambar 14. Rentang waktu penyiraman air terjadi sekitar 3 menit. 
46 | Istas Pratomo Manalu, et. al., Greenhouse Monitoring and Controlling System....,

Message from Node-RED Kotak Masuk $x$
$\begin{aligned} & \text { nodered60@gmail.com } \\ & \text { Penyiraman dilakukan }\end{aligned}$
$\begin{aligned} & \text { nodered60@gmail.com } \\ & \text { kepada saya }\end{aligned}$

Penyiraman telah dilakukan

Gambar 14. Email memeriksa pemupukan

\section{Pengujian Aplikasi}

Pada aplikasi Node-RED yang digunakan untuk membangun sistem Greenhouse Monitoring and Controlling System, Study Case "Strawberry" terdapat dashboard yang memiliki 1 Tombol ON/OFF, 3 gauge, dan 3 graf seperti pada Gambar 15 berikut ini.

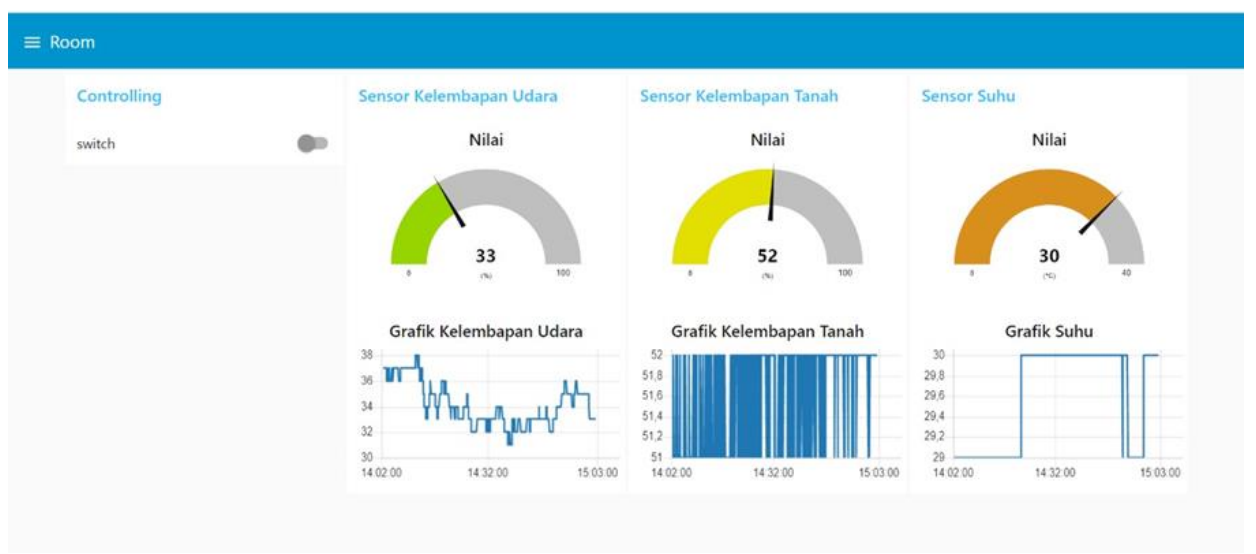

Gambar 15. Tampilan Dashboard dari Greenhouse

Adapun rincian dari aplikasi sistem ini yaitu:

- Tombol Switch, adalah tombol yang digunakan user untuk melakukan pemupukan ke tanaman stroberi rangkaian pada sistem mengalirkan pupuk cair yang telah dibuat sesuai dengan standar pupuk yang baik bagi tanaman stroberi.

- 2 graf dan 2 gauge untuk menampilkan data suhu dan kelembapan udara yang dimasukkan dari Sensor DHT 11 sebagaimana data tersebut yang dapat dibaca dan memastikan apakah komponen berbagi secara langsung.

- 1 graf dan 1 gauge untuk menampilkan data yang diterima oleh Sensor Kelembapan Tanah yang dapat dibaca dan melihat apakah sensor bekerja dengan baik.

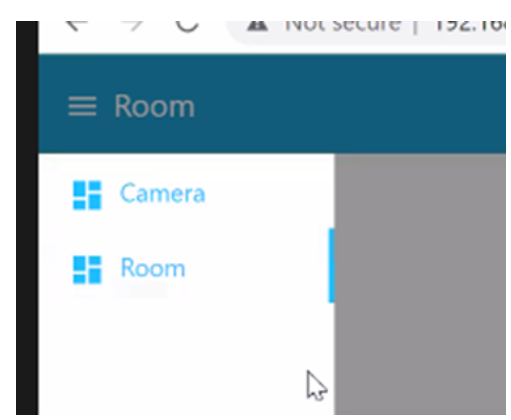

Gambar 16. Menu navbar

Pada tombol menu navbar seperti pada Gambar 16 yang dapat kita temukan di bagian sudut kanan dashboard, muncul pilihan menu Camera yang menampilkan secara langsung gambar yang ditangkap oleh kamera secara real time. Hasil dari modul Kamera dapat dilihat pada Gambar 17 berikut ini. 


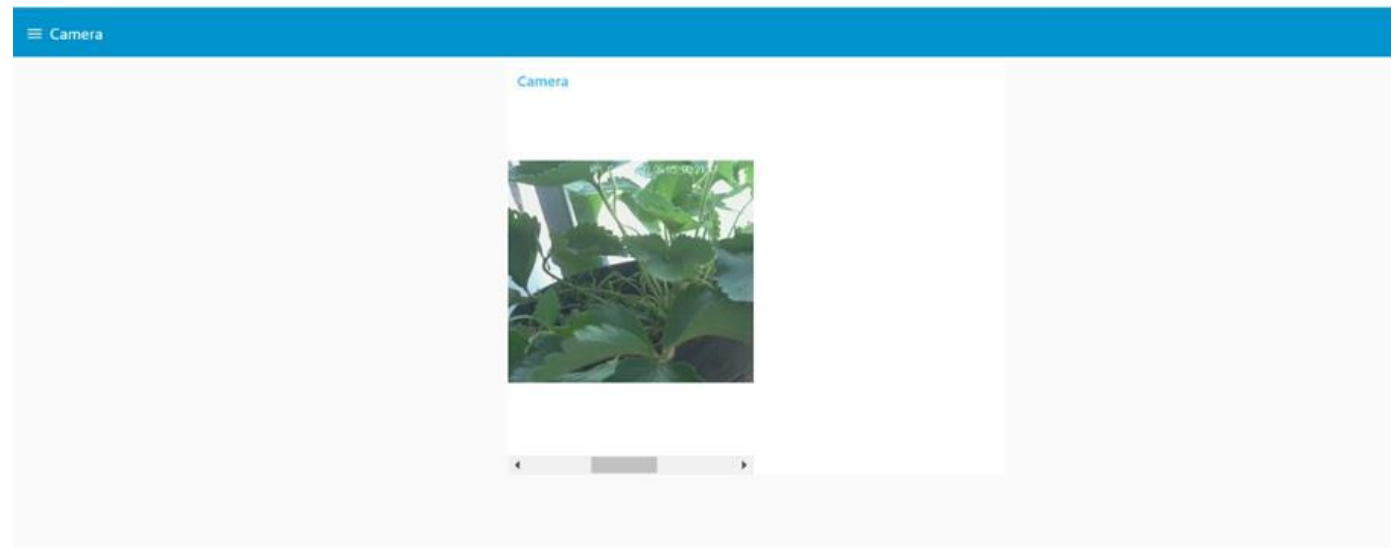

Gambar 17. Hasil dari menu Camera

\section{E. Perbandingan Perkembangan Stroberi di dalam Greenhouse dan di luar Greenhouse}

Pengujian yang dilakukan pada tanaman stroberi menggunakan sistem Aplikasi Node-RED dengan seluruh komponen rangkaian yang dilakukan selama 10 hari oleh tim pengembang didapatkan hasil bahwasannya sistem dapat berfungsi dengan baik. Hal ini dapat dibuktikan dengan melakukan perbandingan antara pemeliharaan tanaman stroberi di dalam Greenhouse menggunakan sistem yang dikembangkan tim dengan tanaman stroberi yang berada di luar Greenhouse. Tanaman stroberi di dalam Greenhouse menerapkan berbagai aktivitas pemeliharaan secara otomatis sedangkan tanaman di luar Greenhouse dibuat di alam terbuka dan dilakukan penyiraman secara manual pada jam 8 pagi dan jam 5 sore. Persamaan yang ada pada kedua tanaman ini adalah kedua tumbuhan memiliki umur yang sama yaitu 3 bulan, ditanam pada media tanah yang menggunakan wadah pot, dan ditanam di daerah Balige, Toba Samosir.

Tabel 4. Pengujian perbandingan kuantitas tanaman selama 10 hari

\begin{tabular}{|c|c|c|c|}
\hline Urutan & Keterangan & Greenhouse & Non-Greenhouse \\
\hline \multirow{2}{*}{ Hari ke-1 } & Jumlah daun & 22 & 10 \\
\hline & Jumlah buah & 8 & 3 \\
\hline \multirow{2}{*}{ Hari ke-2 } & Jumlah daun & 23 & 10 \\
\hline & Jumlah buah & 8 & 3 \\
\hline \multirow{2}{*}{ Hari ke-3 } & Jumlah daun & 23 & 11 \\
\hline & Jumlah buah & 10 & 4 \\
\hline \multirow{2}{*}{ Hari ke-4 } & Jumlah daun & 24 & 12 \\
\hline & Jumlah buah & $12 \& 3$ matang & 5 \\
\hline \multirow{2}{*}{ Hari ke-5 } & Jumlah daun & 25 & 12 \\
\hline & Jumlah buah & 12 & 4 \& 1 matang \\
\hline \multirow{2}{*}{ Hari ke-6 } & Jumlah daun & 25 & 12 \\
\hline & Jumlah buah & $11 \& 1$ matang & 4 \\
\hline \multirow{2}{*}{ Hari ke-7 } & Jumlah daun & 27 & 14 \\
\hline & Jumlah buah & $12 \& 1$ matang & 5 \\
\hline \multirow{2}{*}{ Hari ke-8 } & Jumlah daun & 27 & 17 \\
\hline & Jumlah buah & 13 & $4 \& 1$ matang \\
\hline \multirow{2}{*}{ Hari ke-9 } & Jumlah daun & 30 & 19 \\
\hline & Jumlah buah & 14 & $3 \& 1$ matang \\
\hline \multirow{2}{*}{ Hari ke-10 } & Jumlah daun & 30 & 19 \\
\hline & Jumlah buah & $13 \& 1$ matang & 4 \\
\hline
\end{tabular}


Berdasarkan data yang didapatkan dan tertera pada Tabel 5, bahwasannya sistem ini memberi hasil yang lebih baik untuk diterapkan pada pemeliharaan tanaman stroberi dibandingkan dengan pembudidayaan stroberi secara manual (di luar Greenhouse). Hasil dari tanaman stroberi di dalam Greenhouse lebih unggul jumlah buah dan daun sebagaimana dapat dilihat infomasinya dalam Tabel 5 berikut ini.

Tabel 5. Hasil pengujian perbandingan 10 hari

\begin{tabular}{lll}
\hline Keterangan & $\begin{array}{l}\text { Tanaman stroberi } \\
\text { di dalam greenhouse }\end{array}$ & $\begin{array}{l}\text { Tanaman stroberi } \\
\text { di luar greenhouse }\end{array}$ \\
\hline Buah matang & 6 buah & 3 buah \\
Buah yang dihasilkan & 18 buah & 7 buah \\
Jumlah daun bertambah & 23 & 9
\end{tabular}

Pada peningkatan suhu rata-rata didapatkan pula data bahwasannya suhu di dalam Greenhouse biasanya lebih rendah daripada suhu di luar Greenhouse, walaupun pengujian masih menggunakan 1 kipas.

\section{KESIMPULAN}

Sistem monitoring dan controlling stroberi pada greenhouse telah berhasil dibangun. Sesuai analisis data yang telah dilakukan dapat dinyatakan bahwa masyarakat Toba dapat membudidayakan stroberi dengan metode monitoring dan controlling pada greenhouse. Aktivitas pemantauan (monitoring) untuk data suhu udara, kelembapan udara dan kelembapan tanah dilakukan berdasarkan sensor serta kondisi tanaman berdasarkan tangkapan kamera. Pemantauan dapat dilakukan melalui dashboard Node-RED dengan data suhu udara, kelembapan udara, dan kelembapan tanah dalam bentuk gauge dan grafik garis, sedangkan kondisi tanaman dalam bentuk tab penampil video streaming. Selanjutnya, aktivitas pengendalian (controlling) kelembapan tanah dilakukan melalui penyiraman air menggunakan pompa air dan pemupukan melalui pompa pengalir pupuk cair. Sedangkan suhu udara tidak dapat dikendalikan untuk tetap berada pada suhu $17-25^{\circ} \mathrm{C}$, tetapi dapat menurunkan suhu udara $2^{\circ} \mathrm{C}$ sampai $4^{\circ} \mathrm{C}$ dari suhu di luar Greenhouse. Namun, ada beberapa hal yang perlu ditingkatkan untuk penelitian selanjutnya yaitu ventilasi atau lubang pertukaran udara sebaiknya berjumlah cukup banyak untuk fungsi kipas yang lebih efektif dalam mengganti sirkulasi udara di dalam Greenhouse. Sinar matahari yang cukup terik mempengaruhi tingkat suhu udara, oleh sebab itu sebaiknya bagian atas Greenhouse dilapisi kain transparan atau jaring hitam untuk meminimalkan sinar matahari yang masuk ke dalam Greenhouse. Untuk pengisian wadah air masih secara manual, maka sebaiknya ada pengisian wadah otomatis dengan pengukuran level air menggunakan watermeter.

\section{DAFTAR PUSTAKA}

[1] L. I. M. Kessek, M. Tulung, and C. L. Salaki, "JENIS DAN POPULASI HAMA PADA TANAMAN STROBERI (Fragaria x ananassa Duscesne)," Eugenia, vol. 21, no. 1, pp. 32-44, 2015, doi: 10.35791/eug.21.1.2015.11803.

[2] Z. Hanif and H. Ashari, "Sebaran Stroberi (Fragaria x ananassa) di Indonesia," Pros. Semin. Nas. Pekan Inov. Teknol. Hortik. Nas. Penerapan Inov. Teknol. Hortik. dalam Mendukung Pembang. Hortik. yang Berdaya Saing dan Berbas. Sumberd. Genet. Lokal, pp. 87-95, 2012, doi: 10.13140/RG.2.1.2110.6089.

[3] N. Nasution, M. Rizal, D. Setiawan, and M. A. Hasan, "IoT Dalam Agrobisnis Studi Kasus : Tanaman Selada Dalam Green House," IT J. Res. Dev., vol. 4, no. 2, pp. 86-93, 2020, doi: 10.25299/itjrd.2020.vol4(2).3357.

[4] O. Elijah, A. A. Bakhit, T. A. Rahman, T. H. Chua, S. F. Ausordin, and R. N. B. Razali, "Production of strawberry using internet of things: A review," Indones. J. Electr. Eng. Comput. Sci., vol. 15, no. 3, pp. 1621-1628, 2019, doi: 10.11591/ijeecs.v15.i3.pp1621-1628.

[5] I. K. L. P. Artana, D. M. Wiharta, and Linawati, "RANCANG BANGUN PERTANIAN STROBERI BERBASIS INTERNET OF THINGS," J. SPEKTRUM, vol. 7, no. 4, pp. 1-6, 2020, doi: https://doi.org/10.24843/SPEKTRUM.2020.v07.i04.p1.

[6] R. A. Wijaya, S. W. Lestari, and Mardiono, "Rancang Bangun Alat Monitoring Suhu dan Kelembaban Pada Alat Baby Incubator Berbasis Internet Of Things," J. Teknol., vol. 6, no. 1, pp. 52-70, 2018, doi: 10.31479/jtek.v6i1.5.

[7] R. K. Kodali, V. Jain, and S. Karagwal, "IoT based Smart Greenhouse," in 2016 IEEE Region 10 Humanitarian Technology Conference (R10-HTC), 2017, pp. 1-6, doi: https://doi.org/10.1109/R10-HTC.2016.7906846.

[8] H. Sujadi and Y. Nurhidayat, "SMART GREENHOUSE MONITORING SYSTEM BASED ON INTERNET OF THINGS,” J. J-Ensitec, vol. 06, no. 01, pp. 371-377, 2019, doi: http://dx.doi.org/10.31949/j-ensitec.v6i01.2020.

[9] S. Vatari, A. Bakshi, and T. Thakur, "Green House by using IOT and Cloud Computing," in 2016 IEEE 
International Conference on Recent Trends in Electronics, Information \& Communication Technology (RTEICT), 2017, pp. 246-250, doi: 10.1109/RTEICT.2016.7807821.

[10] M. E. D. W. Branta, "RESPON PERTUMBUHAN DAN HASIL TANAMAN STROBERI (Fragaria sp.) PADA BERBAGAI KONSENTRASI KALIUM DAN GIBERELIN DENGAN HIDROPONIK NFT,” Universitas Pembangunan Nasional "Veteran" Yogyakarta, 2020.

[11] S. Mulyono, M. Qomaruddin, and M. S. Anwar, "Penggunaan Node-RED pada Sistem Monitoring dan Kontrol Green House berbasis Protokol MQTT," J. Transistor Elektro dan Inform. (TRANSISTOR EI), vol. 3, no. 1, pp. 3144, 2018.

[12] D. K. Widyawati, A. Ambarwari, and A. Wahyudi, "Design and Prototype Development of Internet of Things for Greenhouse Monitoring System," in 2020 3rd International Seminar on Research of Information Technology and Intelligent Systems (ISRITI), 2020, pp. 389-393, doi: http://dx.doi.org/10.1109/ISRITI51436.2020.9315487.

[13] A. Kurnia, "Petunjuk Praktis Budi Daya Stroberi," Google Books, 2006.

https://books.google.co.id/books?id=j8jInfxuSyEC (accessed Nov. 05, 2021). 